\title{
Enacting Remembrance Day in the Public Sphere
}

\author{
Noor lqbal
}

\begin{abstract}
:
The form of commemoration offered by Remembrance Day ceremonies works to produce a sense of nationalist patriotism. The 'public history' of the nation, as a mode of self-representation, presents a particular narrative of limited scope, occluding all elements that do not fit its ideological framework. Remembrance Day simultaneously invokes and educates Canadian collective memory and public history, mediated through the contemporary power/knowledge discourse on war.

The values, structure, and 'tendencies of a society' become evident in collective memory and this cultural heritage of society becomes a site at which it is 'visible to itself'.
\end{abstract}

On November 10, 2009, Queen Elizabeth Public School in Edmonton hosted a "trans-Canada Remembrance Day ceremony," digitally linked with Canadian soldiers in Afghanistan. ${ }^{230}$ During this event, teachers, staff, and students gathered to "remember that Remembrance is about more than just remembering those who died a long time ago."231 While remembering wars, like other aspects of the past, is crucial to a deep understanding of the present and allows a greater comprehension of the lives of previous generations, the form of commemoration offered by Remembrance Day ceremonies-such as the one at Queen Elizabeth

\footnotetext{
230 See the appended announcement from Edmonton Public School Board (EPSB). 231 Email circular encouraging EPSB Argyll Centre home education students around the province to connect to the Remembrance Day ceremony via an online link, I0/14/2009.
} 
School-works to produce a sense of nationalist patriotism. The public history of the nation, as a mode of self-representation, presents a particular narrative of limited scope, occluding all elements that do not fit its ideological framework.

Remembrance Day is often seen as a national event in which "young people" are the "constituency whose interests [are] most at stake."232 As historian Graham Carr discusses in "War, History, and the Education of (Canadian) Memory," Remembrance Day ceremonies educate the memory of students by inculcating the "public history of the nation." 233 Remembrance Day ceremonies in schools generally include singing the national anthem, reflections on the sacrifices of soldiers who fought for Canada in conflicts since the First World War, and two minutes of silence at 11 am to honour those who died in battle. Members of the Canadian military are often invited to speak about the personal sacrifice involved in war.

The Queen Elizabeth School ceremony announcement read: "In this live connection with the Canadian troops in Afghanistan, students will participate in a National Remembrance Day ceremony." ${ }^{234}$ By associating

\footnotetext{
232 Graham Carr, "War, History, and the Education of (Canadian) Memory" in Memory, History, Nation: Contested Pasts, ed. Katharine Hodgkin and Susannah Radstone (New York: Routledge, 2003), 60.

233 Ibid., 61.

234 Email circular, 10/14/2009, emphasis in original.
} 
the same kind of mission and cause attributed to First and Second World War soldiers with current Canadian troops fighting on the plains of Kandahar, Remembrance Day ceremonies diachronically homogenize their subjects: a uniformity is assumed across all Canadian military endeavours, allowing contemporary soldiers to stand-in for the more traditional ritual appearance of veterans on Remembrance Day. The emphasis on the 'live' link with the troops serves to update the collective memory: realtime, relevant, and representative, 'our' soldiers today are fighting in 'our' cause, in the same way as we remember those who went before. Present day soldiers are seen as re-enacting the role of First and Second World War soldiers by fulfilling the same role in the national myth of the dominion. Inversely, the justifications for the World Wars are harnessed to support current conflict as well, as affirmed by a Remembrance Day newspaper headline about Canadians in Afghanistan: "The boys didn't die in vain" 235 is a common sentiment in relation to the deaths caused by the World Wars. The story goes on to minutely describe a battle between Canadian forces and Afghan fighters in rhetoric familiar from WWII-era coverage.

Popular Canadian history knows the First World War as the 'crucible of the nation'; in the muddy trenches of

\footnotetext{
235 Edmonton Journal front page article on November II, 2009. The Canadians prevailed against insurmountable "waves of enemy."

<http://www.edmontonjournal.com/news/boys+didn+vain/2209342/story.html>, accessed on November II, 2009.
} 
Europe, Canada came into its own as a nation through the camaraderie and 'heroism' of the troops. ${ }^{236}$ With battles like Vimy Ridge and Passchendaele commanding an elevated status in the founding myth of Canada, Remembrance Day is intimately linked with notions of 'sacrifice' and 'service' to the nation. ${ }^{237}$ The concept of the nation itself works through homogenizing its members: everyone must operate within a common discourse. A national commemoration serves to condense homogeneous sentiment. Because of "a desire for a socially coherent...relationship to the past," ${ }^{238}$ only certain kinds of knowledge about war are acceptable, legitimate, or even possible. "Power and knowledge directly imply one another," ${ }^{239}$ writes Foucault, and through this interaction, the nation-state constitutes its subjects.

236 This bears strong similarities with Alistair Thomson's description of the popular perception of the WWI Anzac troops as described in "Anzac Memories: Putting Popular Memory Theory into Practice in Australia" in The Houses of History: A Critical Reader in Twentieth-Century History and Theory, ed. Anna Green and Kathleen Troup (New York: New York University Press, 1999), 239-252.

237 A particularly flabbergasting incidence of this policy is the newly released "Guide to Citizenship" which deliberately "places a much greater emphasis on Canada's military history" as a space in which Canadians could be heroes. This is something that Immigration Minister Jason Kenney described as essential to the "sense of our common citizenship and where we come from as Canadians."

$<$ http://www.theglobeandmail.com/news/politics/ottawa-moves-to-remodelcanadas-image/article 1358/89/>, accessed November 10, 2009.

As F. Ani wrote in personal correspondence with B. lqbal, "it saddens me that so much of our military history is expressed using this logic. we shouldn't celebrate that fact that canadian blood lubricated the gears of modern war. it should terrify us. our remembrance, and we must remember, is more appropriately articulated as sombre tragedy. [the historian-consultants for this guide] make us smile while taking machine guns bullets. this isn't a nationalist game. it's war." I I/I0/2009. 238 Carr, 7I.

239 Michel Foucault, Discipline and Punish (New York: Random House, 1995), 27. 
This productive power also yields the theoretical possibilities for conceptualizing Remembrance. Remembrance Day is to be a rallying point for all Canadians; therefore, to have "social consensus" about this ritual means to be united in attitude and ideology. ${ }^{240}$ Narratives, stories, and experiences that do not 'fit' the consensus are excluded from articulation. Remembrance Day seems to honour the particular romantic image of the honourable white soldier sacrificing himself in service to the nation. First Nations and Black soldiers, conscientious objectors, veterans suffering from stress disorders, and the internment of Ukrainian- and Japanese-Canadians in the World Wars are clearly not the focus of Remembrance Day, even though they have just as much claim. These memories exist at the margins of the state and are not granted a part in Remembrance Day discourse, perhaps because they are not useful to the project of nation building. In "Anzac Memories," Alistair Thomson interviewed WWI veteran Fred Farrall, who suffered shell-shock during the war. His experience of the war, like that of many others, did not conform to the image of the Australian 'digger'. Paralleling the founding myth of Canada, the stereotype of the glamorous manly Aussie fighters left little room for difference. The "typical narrative" became "oppressive" to those whose experiences did not 'fit' within the reigning power discourse. ${ }^{241}$ Unable to find a space in which to

240 lbid., 72.

241 Thomson in Green and Troup, 240. 
articulate his memories, Farrall's experiences were "misrepresented" by the discourse of remembrance. ${ }^{242}$ Farrall felt "exclude[d] from public affirmation rituals" like Anzac Day and became "uncomfortable about his own identity." 243 The oppression of certain kinds of memory acts upon all members of the group because, as Jan Assmann describes, cultures base their "consciousness of unity and specificity upon [memory] and [derive] formative and normative impulses from it."244

Further, this Remembrance discourse neutralizes the politics surrounding wars like the Afghan 'mission' and reconfigures the concept of supporting the troops in terms of loyalty to the nation. Remembrance Day is seen as a "broad civic obligation to affirm the...contribution [of war] to national security and to uphold the social coherence of the Canadian community." 245 Remembrance Day rituals in disciplinary institutions like schools are often codified. ${ }^{246}$ For example, this "civic duty" 247 is mandatory by way of the Remembrance Day Act in Alberta whereby each school must at least "arrange for a remembrance ceremony" and "ensure the observance

242 lbid.

243 lbid., 247.

244 Jan Assmann, "Collective Memory and Cultural Identity," New German Critique, No. 65 (Spring-Summer, 1995), 128.

245 Carr, 59.

246 Foucault likens schools to hospitals and prisons in the way they organize and (re)form subjects into "docile bodies." For more on the way these institutions are structured, see Michel Foucault, Discipline and Punish, 135-169.

247 Carr, 63. 
of 2 minutes' silence from 11 to 11:02 a.m."248 November 11 is seen as an opportunity to learn about Canadian history in a way which almost invariably invokes the ideal of military service to the nation as the ultimate sacrifice. As a memorial event, Remembrance Day generally places restrictions on its content and can preclude the existence of other interpretations of the past.

The concept of memory is central to Remembrance Day. Most basically, memory refers to the recollection of previous experience. Collective memory is an elaboration of this term that goes beyond the individual to the society. However, it does not encompass all possible lived experiences of the past. Collective memory tells a story. A collective memory is a myth about the past that is held to be true because it is useful within the power structures of the present. However, if the past is to be remembered, as opposed to history being studied, read, or learned, a certain immediacy of the past must be created by which one can "identify both physically and emotionally with lives not lived." ${ }^{249}$ Indeed, the "ideal outcome" of Remembrance Day is often seen as "empathy for the past." ${ }^{250}$ Vicarious identification is seen as the best way to honour the fallen soldiers: ideally, on

\footnotetext{
248 Province of Alberta, Remembrance Day Act, current as of 2002. <http://www.qp.alberta.ca/574.cfm?page=R I6.cfm\&leg_type=Acts\&isbncln=0779703 499>, accessed November II, 2009. 249 Carr, 65. 250 lbid.
} 
Remembrance Day, Canadians are to walk in their shoes for a while in order to better relate to them. Further, this kind of remembering is not the preserve of history buffs or re-enactment aficionados: the entire country is involved with this remembering. The collective memory honoured by Remembrance Day contains moral imperatives to appreciate the 'sacrifices' of soldiers in a particular way. In schools and other institutions, Remembrance Day ceremonies "educate" or "cultivate" collective memory by showing the proper way to remember the past. ${ }^{251}$ In a way, 'education' represents a training or systematization of the mental memory archive.

In terms of school Remembrance Day ceremonies, I argue that students are not necessarily learning about the fallen soldiers as much as being educated in the importance of this kind of remembrance to the nationstate. That is, students experience the ceremony, not a re-play of the conditions of war faced by the Western armies. Students learn that the efforts of those soldiers were noble and that it is a duty to think on them on this anniversary. However, this type of ceremony merely 'tells' about the past, while simultaneously 'showing' the significance of the national myth and collective, conventional 'memory' of the wars. The difference between showing and telling is significant in producing

25 I Carr, 74; Assmann, I3I. 
empathy. Telling remains external, while showing is affective and evocative. Further, the ceremonies generally exclude any other kind of remembrance: marginalized soldiers, those interned during wars, or even of the basic horror and devastation of war are not permitted any real significance in institutionalized Remembrance.

"Age shall not weary them, nor the years condemn," wrote the WWI poet Laurence Binyon. ${ }^{252}$ Through Remembrance Day ceremonies, members of contemporary society are not called upon to inhabit the past', but to go forward in the same spirit as the past. This can be construed in two ways: firstly, that we are to maintain the nation in the way it was understood by those who died, or secondly, that we retrospectively project our vision of the nation onto the past and say, 'yes, this is what they were fighting for.' Both of these understandings of the past operate within a progress narrative that depends on generational continuity.

As Carr points out, commemoration is often construed in filial terms. The unit of change in the enactment of the Remembrance Day ritual is the generation. ${ }^{253}$ That is, difference is not recognized so much within the body of soldiers: that they might lead vastly different lives, have

\footnotetext{
252 "For the Fallen" by Laurence Binyon. This poem is ubiquitously available in relation to Remembrance Day. I accessed it here: <http://oldpoetry.com/opoem/24934-Robert-Laurence-Binyon-For-The-Fallen> on November 10, 2009.

253 Carr, 59.
} 
different reasons for being in the military, and, most importantly, that they experience the wars differently from each other is not relevant to the ceremony. Rather, generations are viewed as relatively stable blocks with similarities in "age, social identity, and historical perspective." 254 The reason the youth are the primary audience of Remembrance Day ceremonies is because they represent the new generation. ${ }^{255}$ The ceremony at Queen Elizabeth School featured "a discussion between a Grade 8 student and his father, who is currently 'serving' in Afghanistan," an opportunity to strengthen the bond between generations, essentially enacting a relay of the torch alluded to in John McCrae's poem "In Flanders Fields." 256

A stanza of this poem was quoted on the Edmonton Public School Board website in the announcement of the Queen Elizabeth School ceremony. The verse chosen is significant in itself, but more interestingly, it appears without segue. This poem, along with the values it espouses, is linked so closely with Remembrance Day that its presence is seen as self explanatory. Similarly, the kind of remembrance such ceremonies invoke is seen as reflecting a capital ' $T$ ' Truth and objective reality. We are called upon to remember the transparent history of the nation, not as seen by subjective

254 lbid.

255 lbid., 60

256 EPSB website announcement, appended. 
individuals, but 'as it really happened." 257 While other interpretations and even experiences of war may abound, they are secondary to the main story-subplots and tangents might add anecdotal interest but are marginalized around the main narrative.

The penultimate lines of "In Flanders Fields" warn that "If ye break faith with us who die/ We shall not sleep, though poppies grow." ${ }^{258}$ While the sun shines and the flowers bloom, those who live on are charged with an imperative to 'keep the faith.' Traditionally recited in Remembrance Day ceremonies, McCrae's poem asserts that the generation that fought did so in the cause of truth. To "break faith" is to question and betray their understanding of reality, to turn traitor to their whole worldview. $^{259}$ Remembrance Day tries to ensure generational continuity by emphasizing empathy and pride for the soldiers.

257 This conception of history raises many questions about empiricism and objectivity-is the goal of history to show the past 'as it really happened'—or in Leopold von Ranke's words, "zeigen, wie es eigentlich gewesen"? Is this even possible?

258 John McCrae, "In Flanders Fields," quoted from the EPSB website announcement, appended.

259 In Foucault's terms, perhaps we can understand breaking faith with the past as enacting an epistemic rupture. The notion of rupture also depends on generational or epochal homogeneity. What is thinkable shifts in the space between epistemes. On a smaller scale, the same process can occur between generations as societal values meld and change. The concept of rupture is also problematic as it assumes an abruptness that is not always (or ever?) evidenced by historical sources. Historical change in terms of concepts, ideas, and viewpoints is rarely neat, complete, or simultaneous across a discourse and even less so within epistemes. Perhaps it is more like a shifting and sliding-after all, we are dealing with human beings! For Foucault's discussion of epistemes, see Michel Foucault, Archeology of Knowledge (London: Routledge Classics, 2002), 212. 
The axiom "lest we forget" is particularly evocative because it reveals a tension between remembrance and forgetting. Those who were born after the war cannot 'forget' it in a literal sense, as they do not have an experiential memory of it. "Forget" is meant in the same collective sense as "remembrance." The dictum urges us to partake in an active re-telling of the myth of war and nation, "lest we forget," as if the past were an echo we might not hear. The word "lest" contains an imperative to act: "we will remember." While "lest we forget" is a call to remember the terrible human suffering and loss of life through war, it also shows a fear, of sorts, that future generations will not care about the causes of the past and will not 'honour the memory' of the soldiers who selflessly gave their lives for the 'freedom of the nation.' The phrase ensures a loyalty to the soldiers, as a homogeneous group, and to the ostensible cause for which they took up arms.

The Remembrance Day ceremony at Queen Elizabeth School served a function. It simultaneously invoked and educated Canadian collective memory and public history, mediated through the contemporary power/knowledge discourse on war. The "cultural heritage" of a society is the site at which it "becomes visible to itself"; the values, structure, and "tendencies of a society" become 
evident in collective memory. ${ }^{260}$ Remembrance, in this narrow sense, precludes other ways of 'keeping the past present' in public memory and space. What other possibilities for Remembrance exist in contemporary Canadian society?

Lest we forget.

260 Assmann, 133. 
APPENDIX

\section{Media Releases}

Friday, November 6, 2009

\section{Good Things Are Happening QUEEN ELIZABETH SCHOOL REMEMBERS BY HOSTING NATIONAL VIRTUAL REMEMBRANCE DAY CEREMONY}

Queen Elizabeth School (9425 - 132 Avenue) will host a trans-Canada Remembrance Day ceremony with Canadian troops in Afghanistan on Tuesday, November 10 from 10:40 - 11:30 a.m. This virtual event will take place via live video-conference and will feature music and guests from 14 participating schools in Quebec, Ontario and Alberta.

The ceremony is a celebration of the achievements and sacrifices made by past and present members of the Canadian military. Part of the ceremony will feature a discussion between a Grade 8 student and his father, who is currently serving in Afghanistan. They will be speaking about what Remembrance Day means to them as a family. Students will also have the opportunity to ask the troops in Afghanistan what Remembrance Day represents to them as they serve. In addition, Peter Goldring, MP for the Alberta riding of Edmonton CentreEast, will be in attendance and will offer the key 
address.

Please join students and staff from across the country for a memorable and educational Remembrance Day ceremony.

The torch; be yours to hold it high.

If ye break faith with us who die

We shall not sleep, though poppies grow

In Flanders fields.

For further information, contact:

Terry Godwaldt, National Virtual Remembrance Day

Ceremony Co-ordinator

Queen Elizabeth School

9425 - 132 Avenue

780.700 .4482

(C) Copyright 2009, Edmonton Public Schools

〈http://epsb.ca/mediareleases/091106.shtml〉, accessed November 10, 2009. 


\section{Bibliography}

Assmann, Jan. "Collective Memory and Cultural Identity." New German Critique. No. 65, Spring-Summer, 1995.

Binyon, Laurence. "For the Fallen." 1939. http://oldpoetry.com/opoem/24934-RobertLaurence-Binyon-For-The-Fallen, accessed November 10, 2009.

Carr, Graham. "War, History, and the Education of (Canadian) Memory" in Memory, History, Nation: Contested Pasts. Ed. Katharine Hodgkin and Susannah Radstone. New York: Routledge, 2003.

Edmonton Public Schools. http://epsb.ca/mediareleases/091106.shtml, accessed November 10, 2009.

Foucault, Michel. Archeology of Knowledge. London: Routledge Classics, 2002.

Foucault, Michel. Discipline and Punish. New York: Random House, 1995.

Thomson, Alistair. "Anzac Memories: Putting Popular Memory Theory into Practice in Australia" in The Houses of History: A Critical Reader in TwentiethCentury History and Theory. Ed. Anna Green and Kathleen Troup. New York: New York University Press, 1999, 230-252.

Government of Alberta. Remembrance Day Act, 2000. http://www.qp.alberta.ca/574.cfm?page=R16.cfm\&le g_type=Acts\&isbncln=0779703499, accessed November 11, 2009. 